\title{
MORTALITY IN ANESTHESIA: A SYSTEMATIC REVIEW
}

\author{
Leandro Gobbo Braz, ${ }^{I}$ Danilo Gobbo Braz, ${ }^{I I}$ Deyvid Santos da Cruz, ${ }^{I}$ Luciano \\ Augusto Fernandes, ${ }^{\mathrm{I}}$ Norma Sueli Pinheiro Módolo, ${ }^{\mathrm{I}}$ José Reinaldo Cerqueira Braz ${ }^{\mathrm{I}}$
}

doi: 10.1590/S1807-59322009001000011

Braz LG, Braz DG, Cruz DS, Fernandes LA, Módolo NSP, Braz JRC. Mortality in anesthesia: a systematic review. Clinics. 2009;64(10):999-1006.

This systematic review of the Brazilian and worldwide literature aims to evaluate the incidence and causes of perioperative and anesthesia-related mortality. Studies were identified by searching the Medline and Scielo databases, followed by a manual search for relevant articles. Our review includes studies published between 1954 and 2007. Each publication was reviewed to identify author(s), study period, data source, perioperative mortality rates, and anesthesia-related mortality rates. Thirty-three trials were assessed. Brazilian and worldwide studies demonstrated a similar decline in anesthesia-related mortality rates, which amounted to fewer than 1 death per 10,000 anesthetics in the past two decades. Perioperative mortality rates also decreased during this period, with fewer than 20 deaths per 10,000 anesthetics in developed countries. Brazilian studies showed higher perioperative mortality rates, from 19 to 51 deaths per 10,000 anesthetics. The majority of perioperative deaths occurred in neonates, children under one year, elderly patients, males, patients of ASA III physical status or poorer, emergency surgeries, during general anesthesia, and cardiac surgery followed by thoracic, vascular, gastroenterologic, pediatric and orthopedic surgeries. The main causes of anesthesia-related mortality were problems with airway management and cardiocirculatory events related to anesthesia and drug administration. Our systematic review of the literature shows that perioperative mortality rates are higher in Brazil than in developed countries, while anesthesiarelated mortality rates are similar in Brazil and in developed countries. Most cases of anesthesia-related mortality are associated with cardiocirculatory and airway events. These data may be useful in developing strategies to prevent anesthesia-related deaths.

KEYWORDS: Anesthesia; Cardiac Arrest; Mortality, Perioperative; Review.

\section{INTRODUCTION}

Anesthesia has the potential to induce physiological changes that may lead to morbidity and mortality. As a result, it is commonly regarded as a high-risk activity. A number of investigators, however, have reported that anesthesia-related mortality rates have declined over the past two decades. This decrease has been attributed to a variety of safety improvements including improved monitoring techniques, the development and widespread adoption of

\footnotetext{
I Department of Anesthesiology, Botucatu Medical School, São Paulo State University (UNESP) - São Paulo/SP, Brazil.

II School of Medicine, Universidade Nove de Julho - São Paulo/SP, Brazil. Email: lbraz@fmb.unesp.br

Tel.: 55143811.6061

Received for publication on April 28, 2009

Accepted for publication on July 03, 2009
}

practice guidelines, and other systematic approaches to error reduction. ${ }^{1,2}$

Nonetheless, trends in the frequency of anesthesiarelated mortality remain controversial. According to a recent review, ${ }^{3}$ the literature reports a wide range of perioperative mortality rates, which is probably due to variable methodologies and differences in operational definitions and reporting sources, as well as a lack of appropriate risk stratification. Numerous studies have examined perioperative mortality. ${ }^{3-31}$ In these reports, the definitions for deaths in which anesthesia was the primary or a contributing cause $\mathrm{e}^{3-35}$ varied widely, as did the time windows for the considered perioperative period. The perioperative period has been defined as intraoperative only, ${ }^{12,14,16,24,33}$ intraoperative and recovery from anesthesia, ${ }^{24,29,31}$ the first 12 postoperative hours, ${ }^{34}$ the first 24 postoperative hours, , ,7,8,11,13,18,20,22,26,28,30,32,33 two 
or three postoperative days,,$^{3,9,10,17,35}$ or seven postoperative days. ${ }^{6,19,21,23,25}$ Furthermore, mortality incidence may depend on the surgical population. Several studies examined all types of surgery, ${ }^{3-5,7-13,15-32,35}$ while others excluded surgeries in ASA V patients, ${ }^{34}$ cardiac surgeries ${ }^{14,24,33}$ or obstetric surgeries. ${ }^{6}$ These wide variations based on methodological differences as reported in the literature make it impossible to detect trends in anesthesia safety. ${ }^{3}$

Large-scale and national studies of anesthesia-related mortality have been performed in some countries to confirm whether the mortality rate has indeed decreased. ${ }^{11,17,20,21,23,25,26,35}$ In Brazil, reliable data on anesthesia-related mortality have been collected, ${ }^{27-31}$ but no nationwide study has been undertaken.

The purpose of our study was to perform a systematic review of the Brazilian and worldwide literature in order to evaluate the incidence and causes of perioperative and anesthesia-related mortality.

\section{METHODS}

The Medline (via PubMed) and Scielo databases were searched using the subject keywords "mortality, cardiac arrest and anesthesia". We also used the "related articles" function on PubMed and Scielo with the references of the studies. Publications were included in our review if their titles or abstracts were available in English or Portuguese and suggested a perioperative mortality rate related to anesthetic management in a general patient population over a specific period of time based on original data from at least 25,000 anesthetics. The review was completed in July 2008. Publications were excluded if the anesthetic management was limited to a particular technique or the patient population was limited to a particular procedure, associated disease state, or age group. Other studies on anesthesia mortality that offered additional relevant information were also examined. Mortality-triggering factors were assigned to one of three groups: (i) surgery-related; (ii) related to patient disease or condition; or (iii) anesthesia-related when anesthesia was the major contributor or represented an additional factor associated with patient disease condition or surgical factor.

Each publication was reviewed in order to identify the author(s), study period, data source, perioperative mortality rate (including all death-triggering factors), and anesthesiarelated mortality rate.

\section{RESULTS}

Database queries identified 33 publications reporting anesthesia-related mortality data, 28 from international investigators (Tables 1 and 2) and 5 publications by Brazilian investigators (Table 3).

Comparison of the literature data reported by investigators from different countries between 1954 and 1989 with those obtained from 1990 to 2006 showed that anesthesiarelated mortality rates decreased from $0.30-7.91$ per 10,000 anesthetics $^{4-13}$ (Table 1) to $0.10-5.70$ per 10,000 anesthetics ${ }^{3,14-26,32-35}$ (Table 3). However, the highest anesthesia-related mortality rates were observed between 1990 and 2006 (3.3 to 5.7 per 10,000 anesthetics) and reported in studies performed in developing countries ${ }^{18,26}$ (Table 2).

In Brazil, reported anesthesia-related mortality rates also declined from 2.28 per 10,000 anesthetics in $1986^{27}$ to 0.12 - 1.12 per 10,000 anesthetics between 1998 and 2006 $28-31$ (Table 3).

Comparison of the literature reported by worldwide investigators from 1954 to 1989 with papers published between 1990 and 2006 demonstrated that perioperative mortality rates declined from 2.4 - 188.9 per 10,000 anesthetics $^{4-13}$ (Table 1) to $1.41-28.2$ per 10,000 anesthetics $^{3,14-23,25,26}$ (Table 2). Once more, the highest anesthesia-related mortality rates for the 1990-2006 period (20.14 to 28.2 per 10,000 anesthetics) were reported by investigators from developing countries ${ }^{15,18,26}$ (Table 2). The studies conducted in Brazil between 1986 and 2006 also revealed increased perioperative mortality rates varying from 19.1 to 51.0 per 10,000 anesthetics ${ }^{27-31}$ (Table 3).

In both Brazilian ${ }^{28,30,31}$ and worldwide $3,9,15,17,20-22,26$ studies, the patient/disease condition represented the major perioperative mortality-triggering factor, followed by surgery and anesthesia. The incidence of mortality caused by surgical factors declined significantly during the last few decades. ${ }^{17}$

Cardiovascular effects caused by the administration of anesthetic drugs and inadequate blood management during hemorrhage and anemia have been the major contributing factors to anesthesia-related mortality during the past twenty

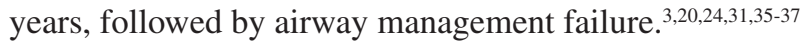

Of the factors associated with the patient condition/ disease or surgery, both Brazilian ${ }^{29,31}$ and worldwide 22,26 studies have pointed to trauma as the major cause of perioperative mortality, followed by end-stage liver disease and liver transplantation-related complications, complications associated with cardiac surgery, and exsanguinating hemorrhage at operation associated with the primary disease.

In newborns and children under one year ${ }^{11,14,21-23,30}$ as well as in the elderly, mortality rates were higher than in young adults. ${ }^{11,12,17,21-23,28,35}$

Poorer American Society of Anesthesiologists physical status (ASA III to V) ${ }^{11,14,29,31,34,35}$ and emergency 
Table 1 - Mortality incidence in patients undergoing anesthesia according to studies performed in different countries between 1954 and 1989

\begin{tabular}{|c|c|c|c|c|}
\hline \multirow{2}{*}{$\begin{array}{l}\text { Investigator and } \\
\text { Year of Publication }\end{array}$} & \multirow{2}{*}{$\begin{array}{l}\text { Time Period and } \\
\text { Data Source }\end{array}$} & \multirow{2}{*}{$\begin{array}{l}\text { Study Population and } \\
\text { Time of Death }\end{array}$} & \multicolumn{2}{|c|}{ Mortality Incidence per 10,000 anesthetics } \\
\hline & & & Perioperative & Anesthesia-Related \\
\hline $\begin{array}{l}\text { Beecher \& Todd } \\
(1954)^{4}\end{array}$ & $\begin{array}{c}1948-1952 \\
\text { Group of } 10 \text { hospitals } \\
\text { USA }\end{array}$ & $\begin{array}{l}599,548 \text { anesthetics } \\
\text { Hospital death }\end{array}$ & 133.05 & 6.40 \\
\hline $\begin{array}{l}\text { Memery } \\
(1965)^{5}\end{array}$ & $\begin{array}{c}1955-1964 \\
\text { Private hospital } \\
\text { USA }\end{array}$ & $\begin{array}{l}69,291 \text { anesthetics } \\
\text { Deaths within } 24 \mathrm{~h}\end{array}$ & 25.84 & 3.18 \\
\hline $\begin{array}{l}\text { Marx et al. } \\
(1973)^{6}\end{array}$ & $\begin{array}{l}1965-1969 \\
\text { Teaching hospital } \\
\text { USA }\end{array}$ & $\begin{array}{c}34,145 \text { anesthetics } \\
\text { Deaths within } 7 \text { days } \\
\text { Excluded: Obstetric patients }\end{array}$ & 188.90 & 7.91 \\
\hline $\begin{array}{l}\text { Bodlander } \\
(1975)^{7}\end{array}$ & $\begin{array}{c}1963-1972 \\
\text { Teaching hospital } \\
\text { Australia } \\
\end{array}$ & $\begin{array}{l}211,130 \text { anesthetics } \\
\text { Deaths within } 24 \mathrm{~h} \text { or failure to } \\
\text { regain consciousness }\end{array}$ & 19.32 & 5.87 \\
\hline $\begin{array}{l}\text { Harrison } \\
(1978)^{8}\end{array}$ & $\begin{array}{c}1967-1976 \\
\text { Teaching hospital } \\
\text { South Africa } \\
\end{array}$ & $\begin{array}{l}240,483 \text { anesthetics } \\
\text { Deaths within } 24 \mathrm{~h}\end{array}$ & 102.04 & 2.20 \\
\hline $\begin{array}{l}\text { Hovi-Viander } \\
(1980)^{9}\end{array}$ & $\begin{array}{c}1975 \\
\text { Group of } 100 \text { hospitals } \\
\text { Finland } \\
\end{array}$ & $\begin{array}{l}338,934 \text { anesthetics } \\
\text { Deaths within } 3 \text { days }\end{array}$ & 18.48 & 1.98 \\
\hline $\begin{array}{l}\text { Turnbull et al. } \\
(1980)^{10}\end{array}$ & $\begin{array}{c}1973-1977 \\
\text { Teaching hospital } \\
\text { Canada } \\
\end{array}$ & $\begin{array}{l}195,232 \text { anesthetics } \\
\text { Deaths within } 48 \mathrm{~h}\end{array}$ & 22.0 & 1.28 \\
\hline $\begin{array}{l}\text { Tiret et al. } \\
(1986)^{11}\end{array}$ & $\begin{array}{c}1978-1982 \\
\text { Group of } 460 \text { hospitals } \\
\text { France } \\
\end{array}$ & $\begin{array}{l}\text { 198,103 anesthetics } \\
\text { Deaths within } 24 \mathrm{~h}\end{array}$ & 18.28 & 3.45 \\
\hline $\begin{array}{l}\text { Olsson \& Hallen } \\
(1988)^{12}\end{array}$ & $\begin{array}{c}1967-1984 \\
\text { Teaching hospital } \\
\text { Sweden }\end{array}$ & $\begin{array}{l}250,543 \text { anesthetics } \\
\text { Deaths in the OR }\end{array}$ & 2.40 & 0.30 \\
\hline $\begin{array}{l}\text { Pitt-Miller } \\
(1989)^{13}\end{array}$ & $\begin{array}{c}1976-1987 \\
\text { General hospital } \\
\text { India }\end{array}$ & $\begin{array}{l}129,107 \text { anesthetics } \\
\text { Deaths within } 24 \mathrm{~h}\end{array}$ & 14.41 & 6.58 \\
\hline
\end{tabular}

OR = Operating Room

surgery ${ }^{11,12,17,21,22,27,29,31}$ have been considered risk factors for perioperative mortality. In addition, higher perioperative mortality incidence has been reported in males. ${ }^{22,28,30,31,35}$

With regard to anesthesia type, perioperative mortality has been reported to be higher in patients undergoing general anesthesia as compared to those undergoing neuraxial anesthesia. ${ }^{20,27,30,31,35}$ Mortality incidence during surgeries carried out under plexus block has been reported as practically zero. ${ }^{29,31,34}$

A higher number of intraoperative deaths have occurred during cardiac surgeries, followed by thoracic, vascular, gastroenterologic, pediatric, and orthopedic surgeries. . $0,22,28,30,31,35^{-1}$

\section{DISCUSSION}

Substantial differences in methodology make it very difficult to compare anesthesia-related mortality rates among studies. ${ }^{3}$ Despite the difficulties, studies undertaken in different countries (Tables 1 and 2) suggest that anesthesia-related mortality rates are lower today than they were 20 years ago. The pioneering study of Beecher and Todd (1954), ${ }^{4}$ which covered the period between 1948 and 1952, reported an anesthesia-related mortality rate of 6.40 per 10,000 anesthetics. Over the past two decades, most of the published studies have reported anesthesiarelated mortality rates ranging from 0.5 to 1.0 per 10,000 anesthetics ${ }^{3,14,22,34,35}$ or even lower, ${ }^{15-17,19,23-25,33}$ which is at least a ten-fold improvement. In support of this assertion, the authors of a nationwide survey performed in France in $1999^{35}$ reported that, in comparison with data obtained in a previous nationwide study (1978-1982), anesthesia-related mortality in France seemed to be reduced ten-fold in that country.

Some Brazilian studies conducted at the same kinds of institutions point to the same trend. According to these 
Table 2 - Mortality incidence in patients receiving anesthesia according to studies performed in different countries between 1990 and 2006

\begin{tabular}{|c|c|c|c|c|}
\hline \multirow{2}{*}{$\begin{array}{l}\text { Investigator and } \\
\text { Year of Publication }\end{array}$} & \multirow{2}{*}{$\begin{array}{l}\text { Time Period and } \\
\text { Data Source }\end{array}$} & \multirow{2}{*}{$\begin{array}{l}\text { Study Population and } \\
\text { Time of Death }\end{array}$} & \multicolumn{2}{|c|}{ Mortality Incidence per 10,000 anesthetics } \\
\hline & & & Perioperative & Anesthesia-Related \\
\hline Chopra et al. $(1990)^{14}$ & $\begin{array}{c}1978-1987 \\
\text { Teaching hospital } \\
\text { Holland }\end{array}$ & $\begin{array}{l}113,074 \text { anesthetics } \\
\text { Deaths in the OR } \\
\text { Excluded: cardiac surgery }\end{array}$ & 1.41 & 0.53 \\
\hline $\begin{array}{l}\text { Harrison } \\
(1990)^{32}\end{array}$ & $\begin{array}{c}1956-1987 \\
\text { Teaching hospital } \\
\text { South Africa } \\
\end{array}$ & $\begin{array}{l}750,00 \text { anesthetics } \\
\text { Deaths within } 24 \mathrm{~h}\end{array}$ & - & 1.90 \\
\hline $\begin{array}{l}\text { Wu et al. } \\
(1991)^{15}\end{array}$ & $\begin{array}{c}1988-1989 \\
\text { General hospital } \\
\text { China } \\
\end{array}$ & $\begin{array}{l}52,128 \text { anesthetics } \\
\text { Deaths within } 7 \text { days }\end{array}$ & 20.14 & 0.40 \\
\hline $\begin{array}{l}\text { Tan \& Delilkan } \\
(1993)^{16}\end{array}$ & $\begin{array}{c}1980-1992 \\
\text { Teaching hospital } \\
\text { Malaysia }\end{array}$ & $\begin{array}{l}155,000 \text { anesthetics } \\
\text { Deaths in the OR }\end{array}$ & 8.06 & 0.39 \\
\hline $\begin{array}{l}\text { Kubota et al. } \\
(1994)^{33}\end{array}$ & $\begin{array}{c}1962-1992 \\
\text { Teaching hospital } \\
\text { Japan } \\
\end{array}$ & $\begin{array}{l}85,708 \text { anesthetics } \\
\text { Deaths in the OR } \\
\text { Excluded: cardiac surgery }\end{array}$ & - & 0.12 \\
\hline $\begin{array}{l}\text { Tikkanen \& Hovi-Viander } \\
(1995)^{17}\end{array}$ & $\begin{array}{l}1986 \\
\text { Group of hospitals } \\
\text { Finland }\end{array}$ & $\begin{array}{l}325,585 \text { anesthetics } \\
\text { Deaths within } 3 \text { days }\end{array}$ & 17.61 & 0.15 \\
\hline $\begin{array}{l}\text { Mckenzie } \\
(1996)^{18}\end{array}$ & $\begin{array}{c}1992 \\
\text { Teaching hospitals } \\
\text { Zimbabwe }\end{array}$ & $\begin{array}{c}34,533 \text { anesthetics } \\
\text { Deaths within } 24 \mathrm{~h} \text { or failure to regain } \\
\text { consciousness }\end{array}$ & 25.80 & 3.30 \\
\hline $\begin{array}{l}\text { Wu et al. } \\
(1997)^{19}\end{array}$ & $\begin{array}{c}1993-1996 \\
\text { General hospital } \\
\text { China } \\
\end{array}$ & $\begin{array}{c}104,600 \text { anesthetics } \\
\text { Deaths within } 7 \text { days or failure to regain } \\
\text { consciousness }\end{array}$ & 3.25 & 0.29 \\
\hline $\begin{array}{l}\text { Arbous et al. } \\
(2001)^{20}\end{array}$ & $\begin{array}{c}1995-1997 \\
\text { Group of hospitals } \\
\text { Holland } \\
\end{array}$ & $\begin{array}{l}869,483 \text { anesthetics } \\
\text { Deaths within } 24 \mathrm{~h}\end{array}$ & 8.80 & 1.40 \\
\hline $\begin{array}{l}\text { Biboulet et al. } \\
(2001)^{34}\end{array}$ & $\begin{array}{c}1989-1995 \\
\text { Teaching hospital } \\
\text { France } \\
\end{array}$ & $\begin{array}{c}101,769 \text { anesthetics } \\
\text { Death within } 12 \mathrm{~h} \\
\text { Excluded: ASA V patients }\end{array}$ & - & 0.60 \\
\hline $\begin{array}{l}\text { Kawashima et al. } \\
(2002)^{21}\end{array}$ & $\begin{array}{c}1999 \\
\text { Group of hospitals } \\
\text { Japan }\end{array}$ & $\begin{array}{l}793,847 \text { anesthetics } \\
\text { Deaths within } 7 \text { days }\end{array}$ & 3.44 & 0.13 \\
\hline $\begin{array}{l}\text { Lagasse } \\
(2002)^{3}\end{array}$ & $\begin{array}{c}1992-1999 \\
\text { Teaching hospitals } \\
\text { USA }\end{array}$ & $\begin{array}{l}\text { 184,472 anesthetics } \\
\text { Deaths within } 2 \text { days }\end{array}$ & 18.90 & 0.77 \\
\hline $\begin{array}{l}\text { Newland et al. } \\
(2002)^{22}\end{array}$ & $\begin{array}{l}1989-1999 \\
\text { Teaching hospital } \\
\text { USA } \\
\end{array}$ & $\begin{array}{l}72,959 \text { anesthetics } \\
\text { Deaths within } 24 \mathrm{~h}\end{array}$ & 14.11 & 0.95 \\
\hline $\begin{array}{l}\text { Kawashima et al. } \\
(2003)^{23}\end{array}$ & $\begin{array}{c}1994-1998 \\
\text { Group of hospitals } \\
\text { Japan }\end{array}$ & $\begin{array}{l}2,363,038 \text { anesthetics } \\
\text { Deaths within } 7 \text { days }\end{array}$ & 4.05 & 0.21 \\
\hline Sprung et al. $(2003)^{24}$ & $\begin{array}{c}\text { 1990-2000 } \\
\text { General hospital } \\
\text { USA }\end{array}$ & $\begin{array}{c}\text { 518,294 anesthetics } \\
\text { Deaths in OR or PARR } \\
\text { Excluded: cardiac surgery }\end{array}$ & - & 0.10 \\
\hline Irita et al. $(2004)^{25}$ & $\begin{array}{c}\text { 1999-2002 } \\
\text { Group of hospitals } \\
\text { Japan }\end{array}$ & $\begin{array}{l}3,855,384 \text { anesthetics } \\
\text { Deaths within } 7 \text { days }\end{array}$ & 6.85 & 0.10 \\
\hline $\begin{array}{l}\text { Charuluxananan et al. } \\
(2005)^{26}\end{array}$ & $\begin{array}{c}\text { 2003-2004 } \\
\text { Group of hospitals } \\
\text { Thailand }\end{array}$ & $\begin{array}{l}163,403 \text { anesthetics } \\
\text { Deaths within } 24 \mathrm{~h}\end{array}$ & 28.20 & 5.70 \\
\hline $\begin{array}{l}\text { Lienhart et al. } \\
(2006)^{35}\end{array}$ & $\begin{array}{c}1999 \\
\text { Group of hospitals } \\
\text { France }\end{array}$ & $\begin{array}{l}7,773,655 \text { anesthetics } \\
\text { Deaths within } 3 \text { days }\end{array}$ & - & 0.54 \\
\hline
\end{tabular}

$\mathrm{OR}=$ Operating room; PARR =Post-anesthesia recovery room. 
Table 3 - Mortality incidence in patients receiving anesthesia according to Brazilian publications between 1980 and 2000

\begin{tabular}{|c|c|c|c|c|}
\hline \multirow{2}{*}{$\begin{array}{l}\text { Investigator and } \\
\text { Year of Publication }\end{array}$} & \multirow{2}{*}{$\begin{array}{l}\text { Time Period and } \\
\text { Data Source }\end{array}$} & \multirow{2}{*}{$\begin{array}{l}\text { Study Population and } \\
\text { Time of Death }\end{array}$} & \multicolumn{2}{|c|}{ Mortality Incidence per 10,000 anesthetics } \\
\hline & & & Perioperative & Anesthesia-Related \\
\hline $\begin{array}{l}\text { Ruiz Neto \& Amaral } \\
(1986)^{27}\end{array}$ & $\begin{array}{c}1982-1984 \\
\text { Teaching hospital } \\
\text { São Paulo (SP) }\end{array}$ & $\begin{array}{l}51,422 \text { anesthetics } \\
\text { Deaths in the OR }\end{array}$ & 19 & 2.28 \\
\hline $\begin{array}{l}\text { Cicarelli et al. } \\
(1998)^{28}\end{array}$ & $\begin{array}{c}1995 \\
\text { Teaching hospital } \\
\text { São Paulo (SP) }\end{array}$ & $\begin{array}{l}25,926 \text { anesthetics } \\
\text { Deaths within } 24 \mathrm{~h}\end{array}$ & 49.78 & 0.77 \\
\hline $\begin{array}{l}\text { Braz et al. } \\
(1999)^{29}\end{array}$ & $\begin{array}{c}1988-1995 \\
\text { Teaching hospital } \\
\text { Botucatu (SP) }\end{array}$ & $\begin{array}{c}58,553 \text { anesthetics } \\
\text { Deaths in the OR or PARR }\end{array}$ & 21.17 & 0.85 \\
\hline $\begin{array}{l}\text { Chan \& Auler Jr } \\
(2002)^{30}\end{array}$ & $\begin{array}{c}1998-1999 \\
\text { Teaching hospital } \\
\text { São Paulo (SP) }\end{array}$ & $\begin{array}{l}82,641 \text { anesthetics } \\
\text { Deaths within } 24 \mathrm{~h}\end{array}$ & 51 & 0.12 \\
\hline $\begin{array}{l}\text { Braz et al. } \\
(2006)^{31}\end{array}$ & $\begin{array}{c}1996-2004 \\
\text { Teaching hospital } \\
\text { Botucatu (SP) }\end{array}$ & $\begin{array}{c}53,718 \text { anesthetics } \\
\text { Deaths in the OR or PARR }\end{array}$ & 21.97 & 1.12 \\
\hline
\end{tabular}

$\mathrm{OR}=$ Operating room; PARR $=$ Post-anesthesia recovery room .

studies, anesthesia-related mortality rates decreased from 2.28 per 10,000 anesthetics in the period of $1982-1984^{27}$ to 0.77 per 10,000 in $1995,{ }^{28}$ and to 0.12 per 10,000 in 1998 1999. ${ }^{30}$ Other Brazilian studies in another institution reported lower and stable anesthesia-related mortality rates ranging from 0.85 per 10,000 anesthetics in $1988-1995^{29}$ to 1.12 per 10,000 anesthetics in 1996-2004. ${ }^{31}$

Considering the differences in patient risk and complexity of surgery five decades ago, it may be easy to conclude that anesthesia safety has dramatically increased over the past two decades. However, surveys of anesthesiarelated mortality carried out in developing countries over this period $^{18,26}$ report rates of 3.30 to 5.70 per 10,000 anesthetics. According to Lagasse (2002), ${ }^{3}$ the number of anesthesiarelated deaths worldwide has not yet stabilized and one cannot detect trends in anesthesia safety until the causes of variation among studies have been fully understood and factored out. Lagasse highlights the fact that the causes of variation could represent real differences in anesthesia safety or just differences in the tools used to measure anesthesiarelated mortality in the various studies.

Although anesthesia-related mortality has been reduced in recent decades, such a reduction is insufficient because, as articulated by Macintosh in $1948,{ }^{36}$ the ideal goal is that zero anesthesia-related deaths should occur. Unfortunately, anesthesia still contributes to major and avoidable adverse effects and deaths, ${ }^{37-39}$ and is still not completely safe in ASA I or II status patients. ${ }^{3}$

In developed countries, perioperative-related mortality also seems to have decreased from 133.4 per 10,000 anesthetics administered in $1948-1952^{4}$ and 188.9 per 10,000 in $1965-1969^{5}$ (Table 1) to fewer than 20 per
10,000 anesthetics ${ }^{3,17,22}$ and even fewer than 10 per 10,000 anesthetics ${ }^{14,16,19-21,23,25}$ (Table 2).

Nonetheless, Brazilian studies suggest no reduction in perioperative-related mortality rates. One study, ${ }^{27}$ covering the period between 1982 and 1984, reported a perioperative mortality rate of 19 per 10,000 anesthetics, while studies performed in the last two decades reported higher incidences ranging from 21 to 51 per 10,000 anesthetics. ${ }^{28,31}$ Studies in developing countries have also reported high perioperative mortality rates (20.14 to 28.2 per 10,000 anesthetics). ${ }^{15,18,26}$ Certain pre-existing morbidities such as trauma, sepsis, and multiple organ failure, which seem to occur at a high incidence in Brazil,${ }^{40}$ and in developing countries as well, ${ }^{41-43}$ have certainly influenced perioperative mortality rates. Thus, weaker clinical statuses of patients undergoing anesthesia seem to be the main factor contributing to the higher perioperative-related mortality rates reported by authors from developing countries in comparison with studies from developed countries.

The higher perioperative mortality rates observed among young adult males both in Brazil ${ }^{29-31}$ and in several other countries ${ }^{20,22,24,35,44}$ can be explained by the fact that men are more predisposed to trauma, violence, and vascular disease than women. Poorer ASA physical status and emergency surgery have been reported as risk factors for perioperative mortality ${ }^{11,22,35}$ and are the only predictive factors of mortality after cardiac arrest. ${ }^{45}$

Some investigators have reported an increased incidence

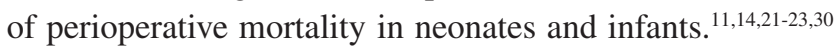
Prematurity, congenital neurological disease, congenital heart disease, and other congenital defects place neonates and infants at a higher anesthesia risk than older children 
and adults. ${ }^{45}$ On the other hand, more recent studies ${ }^{20,24,30,34,45}$ have reported lower perioperative mortality rates in children from 1 to 12 years old.

Some reports ${ }^{11,12,17,21-23,28,35}$ have identified advanced age (70-80 years) as a risk factor. However, in one report, ${ }^{21}$ age itself was not found to be an independent risk factor. Anesthesia-related cardiac arrest and deaths in 70-80 year old patients seem to be increasing, especially during hip arthroplasty surgery. ${ }^{17,24,34}$ In France, the annual rate of anesthetic procedures between 1980 and 1996 increased from 6.6 to 13.5 per 100 people. Increases were greater in the elderly and in those with higher ASA physical status. ${ }^{46}$ If this trend were global, it could indicate improvements in anesthesia safety because instead of an increase, a decrease in anesthesia-related mortality rates has been reported over the past 20 years in France. ${ }^{35}$

Studies suggest that mortality is higher during general anesthesia than during neuraxial anesthesia..$^{24,34,47,48}$ However, this may reflect the fact that patients with hemodynamic instability and a wider variety of more complex cases are surgically treated under general anesthesia. Such cases may include cardiac, thoracic, and neurological operators. Likewise, there may be a bias towards general anesthesia in emergency settings or for patients with coexisting medical conditions. Improved knowledge of neuraxial block physiology and the use of new and safer local anesthetics for the cardiovascular and central nervous systems, together with routinely used oxygen monitoring through pulse oximetry, have all decreased the frequency of major complications during neuraxial anesthesia. ${ }^{49}$ On the other hand, mortality rates of zero have been observed during plexus block. Studies have shown that because there are no major respiratory and cardiovascular changes in plexus block mortality rates can be almost nil, and these low rates happened mainly after the introduction of newer local anesthetics with low myocardial toxicity,. ${ }^{29,31,34,47}$

Deaths caused by airway management failures seem to have decreased. ${ }^{11,20,35}$ Morray et $a l .^{45}$ suggested that the predominance of cardiovascular events in anesthesia-related cardiac arrest and mortality may be related to the frequent use of pulse oximetry and capnography and monitoring hardware that may be more effective in preventing respiratory rather than cardiovascular events. In 24 cases reported by the Danish Closed Claims Registry, four cases were related to airway management and two to ventilation management. ${ }^{38}$ A review of pediatric anesthesia malpractice claims showed that the frequency of respiratory events as primary causes of cardiac arrest has decreased from $51 \%$ in the 1970 s to $41 \%$ in the 1980 s and to $23 \%$ in $1990-2000 .{ }^{47}$ On the other hand, cardiovascular events joined respiratory causes as major risk sources in the 1990s. ${ }^{50}$
Medication-related problems have been reported as predominant factors in cardiovascular events as primary causes of mortality. Findings of the Pediatric Perioperative Cardiac Arrest (POCA) Registry reveal that the rate of medication-related cardiac arrests decreased from $37 \%$ (1994-1997) to $18 \%$ (1998-2004). This decrease was attributed to the increased use of sevoflurane, which is a less severe myocardial depressant than halothane. ${ }^{51}$ In addition, drug error in anesthesia practice is still a matter of concern and can lead to major problems and deaths. ${ }^{29,37}$

In a study of 6,894 cases of the American Society of Anesthesiologists Closed Claims Project covering the period between 1975 and 2000, the proportion of claims for respiratory-related damaging events decreased, while the proportion of claims for cardiovascular-related damaging events increased so that by the period 1992-2000, they occurred at the same frequency (28\%). This trend was associated with an increase in the use of pulse oximetry and end-tidal carbon dioxide monitoring. However, the increase in monitoring and the decrease in death or permanent damage rates seemed unrelated. ${ }^{52}$ Improvements should focus on these two most important areas in order to reduce the number of perioperative deaths. Continued education for anesthesiologists is crucial. However, one study demonstrated that poor practical application rather than lack of knowledge leads to critical incidents. ${ }^{53}$ Major improvements in terms of perioperative morbidity and mortality seem possible with the application of simple anesthesia management principles, such as the routine use of an equipment checklist with documentation of the equipment check, direct availability of an anesthesiologist to lend a hand or troubleshoot when needed, no change of anesthesiologist during anesthesia, the presence of two anesthesia team members in emergency rooms, monitoring neuromuscular blockade, and when necessary, using muscle relaxant and opiate reversal to reduce perioperative morbidity and mortality after surgery and anesthesia. ${ }^{53}$

A period of monitoring in a post-anesthesia care unit is now mandatory following all general, neuraxial, and regional anesthetics. For high-risk patients, continued monitoring in an intensive care unit may reduce anesthetic mortality. Inability to provide or failure to use these facilities may increase anesthesia-related mortality rates.

There are several methodological weaknesses associated with our study. For example, we fail to consider anesthesiarelated mortality reported prior to 1966 because of the temporal limitations of the Medline database. It is, therefore, difficult to verify that all relevant studies predating the Medline database (1966) studies and even after this date have been considered.

In conclusion, our systematic review of the literature 
confirms that perioperative mortality rates are higher in Brazil and other developing countries than in developed countries. Anesthesia-related mortality rates in Brazil and in developed countries are similar and lower than 1 per 10,000 anesthetics. Major risk factors for mortality are apparent for newborns, children under 1 year of age, the elderly, males, patients of ASA III or poorer physical status, emergency surgeries, during general anesthesia, and in cardiac, vascular, thoracic, gastroenterologic, orthopedic, and pediatric surgeries. Medication-related cardiocirculatory events and airway management accounted for the majority of the cases of anesthesia-related mortality. These data may be useful in developing prevention strategies.

\section{REFERENCES}

1. Gaba DM. Anesthesiology as a model for patient safety in health care. BMJ 2000;320:785-8.

2. Cooper JB, Gaba D. No myth: anesthesia is a model for addressing patient safety. Anesthesiology. 2002;97:1335-7.

3. Lagasse RS. Anesthesia safety: model or myth? A review of the published literature and analysis of current original data. Anesthesiology. 2002;97:1609-17.

4. Beecher HK, Todd DP. A study of deaths associated with anesthesia and surgery: based on a study of 559,548 anesthesias in ten institutions 1948-1952, inclusive. Ann Surg. 1954;140:2-35.

5. Memery HN. Anesthesia mortality in private practice: A ten year study. JAMA. 1965;194:1185-8.

6. Marx GF, Mateo CV, Orkin LR. Computer analysis of postanesthetic deaths. Anesthesiology. 1973;39:54-8.

7. Bodlander FM. Deaths associated with anesthesia. Br J Anaesth. 1975; $47: 36-40$.

8. Harrison GG. Death attributable to anaesthesia. A 10 - year survey (1967 - 1976). Br J Anaesth. 1978;50:1041-6.

9. Hovi-Viander M. Death associated with anaesthesia in Finland. Br J Anaesth. 1980;52:483-9.

10. Turnbull KW, Fancourt-Smith PF, Banting GC. Death within 48 hours of anaesthesia at the Vancouver General Hospital. Can Anaesth Soc J. 1980;27:159-63.

11. Tiret L, Desmonts JM, Hatton F, Vourc'h G. Complications associated with anaesthesia - a prospective survey in France. Can Anaesth Soc J. $1986 ; 33: 336-44$

12. Olsson GL, Hallen B. Cardiac arrest during anaesthesia. A computeraided study in 250,543 anaesthetics. Acta Anaesthesiol Scand. 1988;32:653-64.

13. Pitt-Miller P. Deaths within 24 hours of surgical procedures at the Portof-Spain General Hospital. West Indian Med J. 1989;38:148-52.

14. Chopra V, Bovill JG, Spierdijk J. Accidents, near accidents and complications during anaesthesia. A retrospective analysis of a 10-year period in a teaching hospital. Anaesthesia. 1990;45:3-6.

15. Wu KH, Lai KB, Yang CL, Hsich JL, Wei TT. Surgical and anesthetic mortality in Mackay Memorial hospital 1988-1989. Zhonghua Yi Xue Za Zhi (Taipei) .1991;47:187-91.
16. Tan I, Delilkan AE. Anaesthetic contribution to deaths in the operating theatre at the University Hospital Kuala Lumpur - a retrospective survey. Med J Malaysia 1993;48:397-402.

17. Tikkanen J, Hovi-Viander M. Death associated with anaesthesia and surgery in Finland in 1986 compared to 1975. Acta Anaesthesiol Scand 1995;39:262-7.

18. Mckenzie AG. Mortality associated with anaesthesia at Zimbabwean teaching hospitals. S Afr Med J. 1996;86:338-42.

19. Wu KH, Rau RH, Lin CF, Chan YL. Cardiac arrest during anaesthesia in a teaching hospital. A 4 years survey. Int Surg. 1997;82:254-6.

20. Arbous MS, Grobbee DE, van Kleef JW, de Lange JJ, Spoormans HAAJM, Touw P, et al. Mortality associated with anaesthesia: a qualitative analysis to identify risk factors. Anaesthesia. 2001;56:114153.

21. Kawashima Y, Seo N, Morita K, Irita K, Iwao Y, Tsuzaki K, et al Anaesthesia related mortality and morbidity in Japan (1999). J Anesth. 2002;16:319-31.

22. Newland MC, Ellis SJ, Lydiatt CA, Peters KR, Tinker JH, Romberg DJ, et al. Anesthetic-related cardiac arrest and its mortality: a report covering 72,959 anesthetics over 10 years from a US teaching hospital. Anesthesiology. 2002;97:108-15.

23. Kawashima Y, Takahashi S, Suzuki M, Morita K, Irita K, Iwao Y, et al Anaesthesia - related mortality and morbidity over a 5-year period in 2,363,038 patients in Japan. Acta Anaesthesiol Scand. 2003;47:809-17.

24. Sprung J, Warner ME, Contrens ME, Schroeder DR, Beighley CM, Wilson GA, et al. Predictors of survival following cardiac anesthesia in patients undergoing noncardiac surgery. Anesthesiology. 2003;99:25969.

25. Irita K, Kawashima Y, Iwao Y, Seo N, Tsuzaki K, Morita K, et al. Annual mortality and morbidity in operating rooms during 2002 and summary of morbidity and mortality between 1999 and 2002 in Japan: a brief review. Masui. 2004;53:320-35.

26. Charuluxananan S, Chinachoti T, Pulnitiporn A, Klamarong S, Rodanant O Tanudsintum S. The Thai Anaesthesia Incidents Study (THAI Study) of perioperative death: analysis of risk factors. J Med Assoc Thai. 2005;88 (suppl 7):530-40.

27. Ruiz Neto PP, Amaral RVG. Cardiac arrest during anesthesia in a multicenter hospital. A descriptive study. Rev Bras Anestesiol. 1986;36:149-58. 
28. Cicarelli DD, Gotardo AOM, Auler Jr JOC, Olivetti GT, de Oliveira FS Incidence of deaths during the 24-hour period following anesthesia. A review of Hospital das Clínicas - FMUSP records in 1995. Rev Bras Anestesiol. 1998;48:289-94.

29. Braz JRC, da Silva ACM, Carlos E, do Nascimento P Jr, Vianna PTG, Castiglia YMM. Cardiac arrest during anesthesia at a tertiary teaching hospital (1988 to 1996). Rev Bras Anestesiol. 1999;49:257-62.

30. Chan RPC, Auler Jr JOC. Retrospective study of anesthetic deaths in the first 24 hours. Review of 82,641 anesthetics. Rev Bras Anestesiol 2002;52:719-27.

31. Braz LG, Módolo NSP, do Nascimento Jr P, Bruschi BAM, Castiglia YMM, Ganem EM, et al. Perioperative cardiac arrest: a study of 53,718 anaesthetics over $9 \mathrm{yr}$ from a Brazilian teaching hospital. Br J Anaesth 2006;96:569-75.

32. Harrison GG. Death due to anaesthesia at Groote Schuur Hospital, Cape Town- 1956-1987. Part I. Incidence. S Afr Med J. 1990;77:412-5.

33. Kubota Y, Toyoda Y, Kubota H, Ueda Y, Asada A, Okamoto T, et al. Frequency of anesthetic cardiac arrest and death in the operating room at a single general hospital over a 30 year period. J Clin Anesth. 1994;6:227-38.

34. Biboulet P, Aubas P, Dubourdieu J, Rubenovitch J, Capdevila X, d'Athis F. Fatal and non fatal cardiac arrests related to anaesthesia. Can J Anaesth 2001;48:326-32.

35. Lienhart A, Auroy Y, Péquignot F, Benhamou D, Warsgawski J, Bovet M, et al. Survey of anesthesia-related mortality in France. Anesthesiology 2006;105:1087-97.

36. Macintosh R. Deaths under anaesthetics. Br J Anaesth. 1948;21:107-36

37. Abeysekera A, Bergman IJ, Kluger MT, Short TG. Drug error in anaesthetics practice: a review of 896 reports from the Australian Incident Monitoring Study database. Anaesthesia. 2005;60:220-7.

38. Hove LD, Steinmetz J, Christoffersen JK, Moller A, Nielsen J, Schimidt H. Analysis of deaths related to anaesthesia in the period 1996-2004 from closed claims registered by the Danish Patient Insurance Association. Anesthesiology. 2007;106:675-80.

39. Eagle CCP, Davis NJ. Report of the Anaesthetic Mortality Committee of Western Australia 1990-1995. Anaesth Intensive Care. 1997;25:51-9.

40. Brasil. Ministério do Planejamento Orçamento e Gestão. Instituto Brasileiro de Geografia e Estatística. Tabelas completas de mortalidade -2003 [cited 2006 May 15]. Available from URL: www.ibge.gov.br.
41. Krug EG, Dahlberg LL, Mercy JA, Zwibi AB, Lozano R. World report on violence and health. Genebra: World Health Organization, 2002. p. 300-28.

42. Peden MM. World Health Organization. Statistical Annex. In : Peden MM, Scurfield R, Sleer D, editors. World report on road traffic injury prevention. Genebra: World Health Organization, 2004. p. 189-94.

43. Angus DC, Pereira CAP, Silva E. Epidemiology of severe sepsis around the world. Endocr Metab Immune Disord Drug Targets. 2006;6:207-12.

44. Warden JC, Horan BF. Deaths attributed to anesthesia in New South Wales, 1984-1990. Anaesth Intensive Care. 1996;24:66-73.

45. Morray JP, Geiduscheck JM, Ramamoorthy C, Haberkern CM, Hackel A, Caplan RA, et al. Anaesthesia-related cardiac arrest in children: initial findings of the Pediatric Perioperative Cardiac Arrest (POCA) Registry. Anesthesiology. 2000;93:6-14.

46. Clergue F, Auroy Y, Pequignot F, Jougla E, Lienhart A, Laxenaire MC. French survey of anaesthesia in 1996. Anesthesiology. 1999;91:1509-20.

47. Auroy Y, Narchi P, Messiah A, Litt L, Rouvier B, Samii K. Serious complication related to regional anaesthesia: results of a prospective survey in France. Anesthesiology. 1997;87:479-86.

48. Auroy Y, Benhamou D, Bargues L, Eccofey C, Falissard B, Mercier FJ, et al. Major complications of regional anesthesia in France: the SOS Regional Anesthesia Hotline Service. Anesthesiology. 2002;97:1274-80.

49. Kopp SL, Horlocker TT, Warner ME, Hebl JR, Vachon CA, Schroeder DR, et al. Cardiac arrest during neuraxial anesthesia: frequency and predisposing factors associated with survival. Anesth Analg. 2005; 100:855-65.

50. Jimenez N, Posner KL, Cheney FW, Caplan RA, Lee LA, Domino KB. An update on pediatric anesthesia ability: a closed analysis. Anesth Analg. 2007;104:147-53.

51. Bhananker SM, Ramamoorthy C, Geiduschek JM, Posner KL, Domino $\mathrm{KB}$, Haberkern CM, et al. Anesthesia-related cardiac arrest en children: update from the Pediatric Perioperative Cardiac Arrest Registry. Anesth Analg. 2007;105:344-50.

52. Cheney FW, Posner KL, Lee LA, Caplan RA, Domino KB. Trends in anesthesia-related death and brain damage. A closed claims analysis. Anesthesiology. 2006;105:1081-6.

53. Arbous MS, Meursing AEE, van Kleef JW, de Lange JJ, Spoormans $\mathrm{HH}$, Touw P, et al. Impact of anaesthesia management characteristics on severe morbidity and mortality. Anesthesiology. 2005;102:257-68. 